Tissa Elvina Ananda, Ani Wardah, Aminah

Jurnal Mahasiswa BK An-Nur : Berbeda, Bermakna, Mulia

Volume 7 Nomor 1 Tahun 2021

Tersedia Online: https://ojs.uniska-bjm.ac.id/index.php/AN-NUR

p-ISSN. 2460-9722 | e-ISSN. 2622-8297

\title{
PENGEMBANGAN MEDIA POSTER LAYANAN INFORMASI DAMPAK PERNIKAHAN DINI PADA SISWA SMP DI BANJARBARU
}

\author{
Tissa Elvina Ananda ${ }^{1}$, Ani Wardah ${ }^{2}$, Aminah $^{3}$ \\ Universitas Islam Kalimantan Muhammad Arsyad Al-Banjari \\ Tissaelvinaananda98@gmail.com/ 081346390808
}

\begin{abstract}
ABSTRAK
Kalimantan Selatan ialah provinsi di Indonesia dengan jumlah pernikahan dini tertinggi di Indonesia yaitu 39,53\% dari jumlah pernikahan (bersumber pada TIM CNN Indonesia, 09 Maret 2019). Berdasarkan hasil pengamatan peneliti yang dilakukan di SMP Negeri 13 Banjarbaru di kecamatan Cempaka, 8 siswa berhenti sekolah karena menikah, siswa broken home sekitar 50\% dari jumlah seluruh siswa 192 orang. Untuk mengatasi permasalahan pernikahan usia dini perlu pemberian layanan informasi. Dengan adanya pengembangan media ini dapat menghasilkan media poster layanan informasi dampak pernikahan dini pada siswa SMP di Banjarbaru yang teruji keberterimaannya dari aspek kegunaan, kelayakan, ketepatan, dan kemenarikan. Metode penelitian yang digunakan dalam penelitian ini adalah penelitian dan pengembangan (Research and Development). Pengembangan media poster layanan informasi dampak pernikahan dini pada siswa SMP di Banjarbaru mengadaptasi dari strategi pengembangan Borg \& Gall (dalam Sugiono, 2016) yang memiliki tujuh tahap. Media poster dilakukan pengujian oleh ahli validasi yaitu ahli bimbingan konseling, ahli media dan 5 Guru bimbingan konseling di Banjarbaru. Untuk hasil penilaian dari ahli validasi dan 5 Guru bimbingan konseling mendapatkan kategori "Sangat Layak".
\end{abstract}

Kata Kunci: Media Poster, Layanan Informasi, Dampak Pernikahan Dini

\begin{abstract}
South Kalimantan is the province in Indonesia with the highest number of early marriages in Indonesia at $39.53 \%$ of the number of marriages (sourced from the Indonesian CNN TIM, March 9, 2019). Based on the observations of researchers conducted at SMP Negeri 13 Banjarbaru in Cempaka sub-district, 8 students dropped out of school because they were married, students broke home about $50 \%$ of the total 192 students. To overcome the problem of early marriage needs to provide information services. With the development of this media, it can produce a poster service information on the impact of early marriage on junior high school students in Banjarbaru whose acceptance has been tested in terms of usefulness, worthiness, accuracy, and attractiveness. The research method used in this research is research and development (Research and Development). The development of a poster service for information on the impact of early marriage on junior high school students in Banjarbaru adapts from the Borg \& Gall development strategy (in Sugiono, 2016) which has seven stages. The media poster was tested by a validation expert namely counseling expert, media expert and 5 counseling guidance teachers in Banjarbaru. For the results of the assessment of the validation expert and 5 counseling guidance teachers get the category "Very Eligible".
\end{abstract}

Keywords: Poster Media, Information Services, Early Marriage Impac

Dipublikasikan Oleh :

UPT Publikasi dan Pengelolaan Jurnal

Universitas Islam Kalimantan Muhammad Arsyad Al-Banjari Banjarmasin 


\section{PENDAHULUAN}

Media merupakan kata perantara atau pengantar. Gagne menjelaskan bahwa media dapat menciptakan berbagai jenis komponen di lingkungan siswa yang perlu dipelajari siswa. National Education Association (NEA) melaporkan media cetak dan bentuk komunikasi dan perangkat audiovisual. Media harus diteliti, didengar, dan dibaca (Sadiman, 2010). Media mencakup orang, bahan, perlengkapan, ataupun aktivitas yang menghasilkan keadaan yang membuat siswa menggapai pengetahuan, keahlian, serta perilaku. Jadi dalam perihal ini, media bukan cuma perantara semacam Televisi, radio, slide, modul cetak, namun memasukkan orang ataupun orang sebagai sumber pembelajaran ataupun aktivitas semacam dialog, seminar, lapangan, simulasi, serta lain-lain. siswa, ataupun buat tingkatkan keahlian (Mahnun, 2012). Menurut Sadiman (2010) jenis media yang digunakan pada kegiatan pembelajaran adalah sebagai berikut: (1) Media grafis meliputi: Gambar/foto, sketsa, diagram, grafik, poster, papan flanel, papan buletin. (2) Media Audio meliputi: Radio, alat perekam pita magnetik, laboratorium bahasa. (3) Media Proyeksi Diam meliputi: Televisi (TV), video, permainan dan simulasi.

Poster merupakan_suatu kalimat menarik dan biasanya disertai gambar untuk menyampaikan informasi atau himbauan tertentu.

Menurut Hamzah S. (dalam Yaszak, 2015) poster adalah gambar besar, yang menekankan satu atau dua ide utama, sehingga dapat dipahami dengan melihat pada gambar. Dengan demikian, dapat disimpulkan bahwa poster merupakan gambar media yang memiliki sifat persuasif yang tinggi karena menghadirkan masalah yang membangkitkan rasa ingin tahu yang kuat dari penonton. Beberapa fitur poster antara lain lukisan / gambar, mudah diingat, dapat dibaca pendek, dapat dipasang dan diposting di mana saja, ide dan niat sesuai dengan fakta yang disajikan, dan teks yang ringkas, jelas dan bermakna.

Prayitno (dalam Fitri, Ifdil, \& Neviyarni. 2016) berpendapat bahwa layanan informasi adalah layanan yang mengatasi kekurangan individu dalam informasi yang diperlukan. Dalam hal pengiriman layanan informasi, konselor bimbingan hanya menggunakan ceramah, pertanyaan dan jawaban, dan Prayitno (dalam Fitri, Ifdil, \& Neviyarni. 2016) menyatakan bahwa layanan informasi merupakan Layanan yang berusaha memenuhi kekurangan informasi diperlukan informasi. Cara menyampaikan informasi Instruksi dan layanan Konseling guru dapat menggunakan metode ceramah, menjawab pertanyaan, dan diskusi. Menurut Tohirin (dalam Efendi, 2013) menggunakan teknik yang sering digunakan untuk layanan informasi, teknik yang paling umum digunakan oleh untuk menyampaikan informasi tentang kegiatan panduan dan layanan konseling seperti ceramah, fonograf, dan jawaban, dan diskusi; teknik penargetan melalui media; teknik rekayasa acara khusus. Layanan informasi dilakukan melalui media khusus, media tulis, media gambar, poster, dan media elektronik, tape recorder, film televisi, internet, dan banyak lagi.

Pernikahan dini adalah awal pernikahan dan diikuti oleh dua pasangan berusia 18 tahun. Jika pria lebih tua jika tidak lebih tua (18 tahun) maka untuk pernikahan berikutnya mungkin disebut perkawinan dini. Dari hasil penelitian Mubasyaroh (2016), ada beberapa efek negatif dari pernikahan dini, yaitu: mengajar anak-anak menjadi terganggu, kemiskinan, kekerasan dalam rumah tangga (kekerasan dalam rumah tangga), krisis kepercayaan diri, berat badan lahir rendah (BBLR), dan peningkatan risiko komplikasi medis dan kematian.

Faktor selama pernikahan dini dengan siswa / remaja seperti kurangnya pemahaman tentang kesehatan reproduksi, meskipun mudah bagi remaja untuk mengakses internet tanpa batasan, faktor ekonomi adalah penyebab kebutuhan perumahan yang belum matang. Biasanya faktor ini terjadi karena perkawinan atau kehilangan karena kurangnya biaya pendidikan. Faktor lain yang terjadi sejak pernikahan dini adalah faktor tradisi /adat / agama. Informasi tentang pendidikan reproduksi dan seksualitas dianggap tabu untuk dibicarakan tentang remaja. Hal ini menjadi salah satu alasanremaja tidak mengetahui tentang seksualitas dan reproduksi sehingga remaja atau berusaha menemukan diri mereka menggunakan internet.

Untuk mengatasi masalah pernikahan dini, guru bimbingan dan konseling harus memberikan informasi tentang efek kehamilan dini. Hingga kini, Guru Bimbingan Konseling melakukan pemberian layanan bimbingan dan konseling melalui tanya jawab, diskusi, dan ceramah. Proses pelayanannya monoton dan membosankan bagi para siswa. Ini merupakan kendala dan masalah bimbingan dan bimbingan guru karena tidak ada media untuk memfasilitasi bimbingan dan bimbingan guru untuk menyediakan layanan bimbingan. Untuk memfasilitasi, memfasilitasi pemahaman, dan melibatkan siswa, harus dilengkapi dengan media pembelajaran, termasuk media poster sebagai media

Dipublikasikan Oleh :

UPT Publikasi dan Pengelolaan Jurnal

Universitas Islam Kalimantan Muhammad Arsyad Al-Banjari Banjarmasin 
visual yang dapat digunakan dalam proses memberikan layanan kepada siswa.

\section{METODE}

Metode penelitian yang digunakan dalam penelitian ini adalah penelitian dan pengembangan (Research and Development) yang mengadaptasi dari strategi pengembangan Borg \& Gall yang memiliki tujuh tahap yaitu terdiri dari identifikasi kebutuhan, perumusan tujuan, pembuatan media, validasi produk, revisi produk, dan pengemasan media poster. Instrumen pengumpul data dalam pengembangan media poster menggunakan instrumen berupa angket. Angket berisi sejumlah pernyataan tertulis yang digunakan untuk memperoleh informasi dari ahli dan pengguna produk mengenai kegunaan, ketepatan, kelayakan, dan kemenerikan dari media yang dikembangkan. Instrumen pengumpulan data yang digunakan oleh ahli bimbingan konseling, ahli media, serta Guru bimbingan dan konseling selaku calon penggunaa produk. Peneliti mengumpulkan data dengan menggunakan data angket yang berpedoman pada Skala likert sebagai alat ukur. Skala ini berupa suatu pertanyaan dengan empat tanggapan yaitu kegunaan, kelayakan, ketepatan dan kemenarikan. Untuk keperluan kuantitatif, jawaban dapat diberi skor-skor dan selanjutnya data intervalnya dianalisis dengan menghitung persentase rata-rata jawaban dari calon pengguna produk. Adapun untuk analisis persentase rata-rata jawaban peneliti menggunakan rumus:

$$
\mathrm{P}=\frac{\mathrm{F}}{\mathrm{N}} \times 100 \%
$$

P: Angka Persentase

F: Skor yang diperoleh

N: Skor Maksimal

Adapun instrument skor penilaian oleh ahli validasi menurut Sugiono (2016) sebagai berikut:

Tabel 1. Kriteria skor yang digunakan penelitian pengembangan dalam memberikan penilaian oleh validasi ahli

\begin{tabular}{|c|c|}
\hline Kriteria & Skor \\
\hline Sangat setuju (SS) & 4 \\
\hline Setuju (S) & 3 \\
\hline Tidak Setuju (TS) & 2 \\
\hline Sangat Tidak Setuju (STS) & 1 \\
\hline
\end{tabular}

Selanjutnya, untuk menghitung persentase kelayakan pengembangan media dari setiap aspek menggunakan rumus skala likert. dengan rumus sebagai berikut:

$$
\begin{aligned}
& \mathrm{P}=\sum \mathrm{x} \quad \mathrm{x} 100 \% \\
& -\sum \mathrm{xi}
\end{aligned}
$$

Keterangan:

$\mathrm{P}$ : Persentase

$\sum \mathrm{x}$ : Jumlah jawaban responden dalam satu item

$\sum x i$ : Jumlah nilai ideal dalam item

Tabel 2 Kriteria skor kelayakan pengembangan media poster

\begin{tabular}{|l|l|}
\hline Skor Rata-rata (\%) & Kategori \\
\hline $0 \%-25 \%$ & Tidak layak \\
\hline $26 \%-50 \%$ & Kurang layak \\
\hline $51 \%-75 \%$ & Layak \\
\hline $76 \%-100 \%$ & Sangat layak \\
\hline
\end{tabular}

Dipublikasikan Oleh :

UPT Publikasi dan Pengelolaan Jurnal

Universitas Islam Kalimantan Muhammad Arsyad Al-Banjari Banjarmasin 


\section{HASIL DAN PEMBAHASAN}

Hasil penelitian dari setiap tahapan prosedur pengembangan yang dilakukan adalah sebagai berikut: (1) identifikasi kebutuhan peneliti ingin mengembangkan media poster layanan informasi dampak pernikahan dini pada siswa agar dapat memotivasi siswa untuk tetap bersekolah dan dapat melanjutkan ke jenjang SMA hingga ke perguruan tinggi, menghindari terjadinya pernikahan dini yang dilakukan oleh siswa nantinya, dan memberikan variasi Guru Bimbingan Konseling dalam memberikan layanan informasi. (2) Perumusan Tujuan dalam pengembangan media poster ini dimaksud agar mempermudah Guru bimbingan konseling dalam memberikan layanan informasi pada siswa dan siswa memiliki gambaran dan informasi tentang dampakdampak pernikahan dini. (3) Pembuatan media. Gambar kartun yang digunakan peneliti untuk media poster diambil dari internet dan aplikasi Canva, Picsart dan Pinterest. Pada isi poster peneliti membuat 6 poster yang terdiri dari 1 poster tentang dasar-dasar pernikahan dini, dan 5 poster tentang dampak dari pernikahan dini. Selanjutnya peneliti mendesain dan membuat media poster menggunakan aplikasi Canva. Media poster dicetak dengan ukuran A-3. (4) Validasi Produk pada pengembangan media poster di validasi oleh beberapa ahli yaitu: Ahli Bimbingan Konseling, Ahli Media, dan 5 orang Guru Bimbingan Konseling sebagai uji pengguna. (5) Revisi produk. Setelah media poster divalidasi oleh validator ahli dan uji pengguna maka akan didapat saran oleh validator ahli dan uji pengguna diantaranya dari ahli bimbingan konseling dimana dilakukan sedikit revisi dibagian kata dalam poster "mencegah" dapat diganti "untuk tidak melakukan", serta tambahkan satu poster lagi tentang dampak masa muda yang tidak didapatkan oleh siswa SMP yang melakukan pernikahan dini. Selanjutnya dari ahli media dan uji pengguna (guru bimbingan konseling) SMPN 4 Banjarbaru dilakukan sedikit revisi di poster dampak kesehatan terdapat kata yang salah yaitu "kompilasi" diganti dengan "komplikasi".

(6) Pengembangan media. Media poster di uji pengguna oleh 5 Guru Bimbingan Konseling di SMP Banjarbaru terdiri dari SMPN 13 Banjarbaru, SMPN 3 Banjarbaru, SMPN 4 Banjarbaru, SMPN 15 Banjarbaru, dan SMP IT Robbani Banjarbaru.

Dari pengembangan media poster yang dikembangkan oleh peneliti dan di validasi oleh ahli bimbingan konseling, ahli media, dan 5 Guru bimbingan konseling SMP di Banjarbaru sebagai uji pengguna mendapatkan penilaian dengan angka rata- rata persentase $85,15 \%$ dengan kategori "Sangat Layak".

\section{PENUTUP}

Berdasarkan dari uraian dan hasil pengembangan yang dikemukakan diatas maka kami berkesimpulan sebagai berikut: (1) Peneliti telah mengembangkan media poster tentang dampak pernikahan dini sebagai bahan ajar untuk pemberian layanan informasi bimbingan konseling pada siswa SMP. (2) Media poster ini dibuat menggunakan aplikasi Canva, untuk gambar yang terdapat di media poster diambil dari internet, aplikasi Canva, Picsart, Pinterest dan dicetak dengan ukuran A-3.

Implikasi dari pengembangan media poster ini dapat berguna untuk memberikan motivasi dan ideide kreatif bagi para Guru Bimbingan Konseling dan Guru mata pelajaran lainnya untuk mengembangkan media poster atau media lainnya dalam melakukan layanan bimbingan konseling dan mata pelajaran lainnya.

Saran: (1) Untuk peneliti nantinya dapat mengembangkan media poster dengan tema berbeda dan membuat pengembangan media lainnya sehingga dapat memberikan layanan bimbingan konseling secara bervariasi. (2) Untuk Guru Bimbingan Konseling dapat menerapkan media poster ini sebagai bahan ajar untuk pemberian layanan bimbingan konseling pada siswa. (3) Untuk siswa dapat mengetahui dampak-dampak dari pernikahan dini dan dapat merencanakan perkembangan diri secara optimal.

\section{REFERENSI}

Bastomi, H. (2016). Pernikahan Dini dan Dampaknya (Tinjauan Batas Umur Perkawinan Menurut Hukum Islam dan Hukum Perkawinan Indonesia). Yudisia: Jurnal Pemikiran Hukum dan Hukum Islam, 7(2), 354-384.

Desiyanti, I. W., (2015). Faktor-faktor yang berhubungan terhadap pernikahan dini pada pasangan usia subur di kecamatan Mapanget Kota Manado. JIKMU. 5(2); 270-280.

Djamilah, D., \& Kartikawati, R. (2014). Dampak Perkawinan Anak di Indonesia. Jurnal Studi Pemuda, 3(1), 1-16.

Efendi, M. (2013). Pengembangan Media Blog Dalam Layanan Informasi Bimbingan Dan Konseling. Jurnal BK UNESA, 1(1).

Fitri, E., Ifdil, I., \& Neviyarni, S. (2016). Efektivitas layanan informasi dengan menggunakan

Dipublikasikan Oleh :

UPT Publikasi dan Pengelolaan Jurnal

Universitas Islam Kalimantan Muhammad Arsyad Al-Banjari Banjarmasin 
Tissa Elvina Ananda

Jurnal Mahasiswa BK An-Nur : Berbeda, Bermakna, Mulia

Volume....Nomor....., Tahun

Tersedia Online: https://ojs.uniska-bjm.ac.id/index.php/AN-NUR

p-ISSN. 2460-9722

e-ISSN. 2622-8297

metode blended learning untuk meningkatkan motivasi belajar. Jurnal Psikologi Pendidikan dan Konseling: Jurnal Kajian Psikologi Pendidikan dan Bimbingan Konseling, 2(2), 84-92.

Mahnun, N. (2012). Media pembelajaran (kajian terhadap langkah-langkah pemilihan media dan implementasinya dalam pembelajaran). AnNida', 37(1), 27-34.

Sadiman, Arief S. (2010). Media Pendidikan. Jakarta: Raja Grafindo Persada. 